\title{
TINJAUAN YURIDIS KEBIJAKAN WORK FROM HOME BERDASARKAN UNDANG-UNDANG KETENAGAKERJAAN
}

\author{
Nanang Rudi Hartono, Amalia Suci Ramadhani; Fakultas Hukum Universitas Islam Balitar, \\ Jl. Mojopahit No.12A, Blitar, Jawa Timur; E-mail: nrhartonok15@gmail.com, \\ amaliasuci705@gmail.com
}

\begin{abstract}
Abstrak
Tujuan penelitian ini adalah untuk memberikan penjelasan tinjauan yuridis kebijakan Work From Home berdasarkan Undang-undang Ketenagakerjaan dan menjelaskan sanksi maupun solusi jika pengusaha tidak dapat memberikan hak bagi pekerja yang bekerja dari rumah. Penelitian ini menggunakan metode penelitian hukum normatif dengan pendekatan yuridis normatif. Hasil penelitian ini adalah bahwa kebijakan Work From Home tidak memiliki sanksi karena hanya suatu himbauan. Bagi perusahan yang tidak dapat mempekerjakan pekerjanya dari rumah harus menyediakan APD. Pembayaran tunjangan yang harus dibayarkan dimasa pandemi seharusnya tidak boleh diangsur karena telah diatur oleh undang-undang yang memiliki kedudukan di atasnya.

Kata Kunci: Kebijakan Pemerintah, Work from Home, UU Ketenagakerjaan

Abstrak

The purpose of this research is to give explanation about the juridical view of the policy of work from home based on the labour laws dan explain the sanction and the solution if the employer can't give the salary to their worker who work from home. The method of this research using normative legal research with normative juridical approach method. The result of this research is that the policy of work from home doesn't have any sanction cause it's just an appeal. For the company which can't make their workers work from home should serve personal health protictive equipment. Payment of allowance in this pandemic shouldn't be paid installment cause it has been regulated in a law of a higher position
\end{abstract}

Keywords: Government Policy, Work From Home, Labour Law

\section{PENDAHULUAN}

\section{Latar Belakang}

Corona Virus Disease 2019 (Covid-19) adalah virus yang menyerang saluran pernapasan yang pertama kali terdeteksi di Wuhan. Virus ini lalu menyebar ke berbagai negara di dunia dan mulai diumumkan menjadi pandemi global oleh WHO pada 11 Maret 2020. Waktu itu Indonesia masih berada di zona nyaman sampai satu persatu kasus mulai bermunculan dan jumlahnya terus bertambah hingga sekarang. ${ }^{1}$

Sejak awal kemunculannya, virus ini telah membawa dampak bagi berbagai sektor, terutama sektor perekonomian. Perusahaan yang mengandalkan hubungan kerja sama dengan Cina harus merasakan dampak pertama kali. Beberapa perusahaan terkendala bahan baku yang biasanya diimpor dari Cina, reseller barang dari Cina harus bersabar untuk mendapatkan barangdan tempat wisata yang biasanya dikunjungi turis Cina menjadi sepi.

Setelah Indonesia melaporkan adanya kasus pertama dan mulai bermunculan kasuskasus selanjutnya, pemerintah mulai membuat beberapa kebijakan. Karena virus corona dikategorikan sebagai penyakit menular yang menyebabkan kedaruratan kesehatan

\footnotetext{
${ }^{1}$ Ega Ramadayanti. 2020. Covid-19 dalam Perspektif One Health Approach dan Law Enforcement, fh.unpad.ac.id diakses tanggal 13 April 2020.
} 
masyarakat. Diantara kebijakan tersebut adalah sosial distancing dan work from home. Hal ini berdampak besar bagi masyarakat Indonesia karena pada dasarnya masyarakat Indonesia memiliki jenis pekerjaan yang beragam dan tidak semua pekerjaan dapat dilakukan dengan work from home.

Bagi para pekerja formal, work from home bukanlah masalah serius karena mereka bisa tetap mengerjakan pekerjaannya tanpa terlalu banyak kendala dan upah yang diperoleh sudah jelas. Namun masalah muncul bagi para pekerja informal. Mereka yang bekerja hanya untuk sehari makan, buruh-buruh pabrik dan pedagang kecil tentunya lebih terdampak. Macetnya pendistribusian barang, terganggunya hubungan bisnis, pemotongan gaji karyawan hingga PHK menjadi masalah baru akibat kebijakan work from home. Pasalnya kebijakan ini dilematis bagi perusahaan. Tidak semua perusahaan dapat membuat karyawannya bekerja dari rumah karena alat berat tidak mungkin dibawa ke rumah. Permasalahan yang lain adalah krisis yang di alami perusahaan akibat menurunnya produksi dan rendahnya permintaan pasar, sehingga beberapa perusahaan terpaksa mengurangi jumlah karyawan untuk efisiensi. Beberapa perusahaan yang lain bahkan hanya membayar upah karyawan work from home mereka hanya setengahnya.

Meskipun dalam UU Ketenagakerjaan telah diatur sistem pengupahan dalam Pasal 90 Undang-Undang Republik Indonesia Nomor 13 Tahun 2003 tentang Ketenagakerjaan (UUK) menyebutkan, "pengusaha dilarang membayar upah lebih rendah dari upah minimum sebagaimana dimaksud dalam Pasal 89". ${ }^{2} \mathrm{Jadi}$, sudah jelas para pengusaha tidak boleh memberi upah buruh lebih sedikit dari pada upah minimum selama belum ada penangguhan upah dan tetap membayar upah berdasarkan peraturan perundanganundangan yang berlaku. Demikian pula Pasal 151 ayat(1) UUK mengatur bahwa "pengusaha, pekerja/buruh, serikat pekerja/serikat buruh, dan pemerintah, dengan segala upaya harus mengusahakan agar jangan terjadi Pemutusan Hubungan Kerja (PHK)". Maka dari itu, pemerintah memiliki kewajiban melakukan upaya agar tidak ada buruh/pekerja yang di PHK. ${ }^{3}$

Namun saat ini masih banyak perusahaan yang melakukan pelanggaran ketenagakerjaan. Pada dasarnya, melakukan PHK kepada karyawan untuk efisiensi diperbolehkan, namun bagi karyawan tidak bersalah dan di tengah pandemi tentunya memiliki aturan tersendiri. Hal ini menjadi penting untuk dibahas karena berdampak besar bagi masyarakat. Sehingga menjadi urgen untuk meneliti tinjauan yuridis work from home berdasarkan Undang-Undang Ketenagakerjaan dan sanksi serta solusi bagi perusahaan terkait kebijakan tersebut.

2Undang-Undang Republik Indonesia Nomor 13 Tahun 2003 tentang Ketenagakerjaan.

${ }^{3}$ Admin. Bermasalah Terkait Pekerjaan Karena Pandemi COVID-19?: 16 Kantor LBH-YLBHI Membuka Posko Pengaduan Bantuan Hukum Online. lbhyogyakarta.org. diakses 13 April 2020 


\section{METODE PENELITIAN}

Penelitian ini menggunakan metode penelitian normatif. Penelitian hukum normatif lebih condong melihat hukum sebagai disiplin preskriptif yang berarti dalam meneliti hukum lebih melihat kepada sudut pandang ketentuan perundang-undangan. ${ }^{4}$

Di Indonesia, penelitian hukum normatif memiliki kemiripan dengan penelitian hukum common law. Kemiripannya terlihat dari kecenderungan penelitian hukum common law kepada aspek praktis yaitu biasanya digunakan oleh praktisi hukum untuk menyelesaikan masalah hukum konkret (perkara hukum tertentu). Masalah hukum disini bentuknya bisa berupa sengketa atau hanya untuk menggali tentang dimana dan bagaimana masalah tersebut diatur. Maka dari itu dilakukanlah penelitian melalui faktafakta hukum, peraturan hukum dan kasus-kasus yang relevan dengan permasalahan yang sedang dihadapi. ${ }^{5}$

Penelitian ini dilakukan berdasarkan kebijakan baru yang diambil Pemerintah Indonesia yaitu work from home yang diakibatkan oleh pandemi Covid 19 berdasarkan undang-undang ketenagakerjaan. Guna memberi jawaban permasalahan yang dibahas dalam penelitian ini, penulis menggunakan penelitian hukum normatif.

Dalam melakukan penelitian, data-data yang dikumpulkan biasanya diperoleh dari dua cara. Data yang asalnya langsung dari masyarakat dan data yang berasal dari bahanbahan pustaka. Data yang bersumber langsung dari masyarakat disebut data primer. Sedangkan data yang bersumber dari bahan pustaka disebut data sekunder.

Pada penelitian yuridis normatif, digunakan data sekunder untuk menunjang penelitiannya. Dalam penelitian ini data sekunder dibagi menjadi tiga bagian yaitu:

a. Bahan Hukum Primer yaitu bahan-bahan hukum yang berupa peraturan perundangundangan yang berkaitan dengan masalah yang dibahas dalam penelitian ini yaitu:

1. UUD 1945

2. Undang-Undang Republik Indonesia Nomor 13 Tahun 2003 tentang Ketenagakerjaan

3. Keputusan Kepala Badan Nasional Penanggulangan Bencana No. 13A Tahun 2020 tentang Perpanjangan Status Keadaan Tertentu Darurat Bencana Wabah Penyakit Akibat Virus Corona di Indonesia.

4. Surat Edaran Menteri Pendayagunaan Aparatur Negara dan Reformasi Birokrasi No. 19 Tahun 2020 tentang Penyesuaian Sistem Kerja Aparatur Sipil Negara Dalam Upaya Pencegahan Penyebaran Covid 19 di Lingkungan Instansi Pemerintah sebagaimana yang telah diubah dengan Surat Edaran Menteri Pendayagunaan Aparatur Negara dan Reformasi Birokrasi Nomor 34 Tahun2020 tentang Perubahan atas Surat Edaran Menteri Pendayagunaan Aparatur Negara dan Reformasi Birokrasi Nomor 19 Tahun 2020 tentang Penyesuaian Sistem Kerjaaparatur Sipil

${ }^{4} \mathrm{M}$. Taufan Perdana, Moh. Alfaris, Anik Iftitah, "Kewenangan BAWASLU Dalam Pilkada2020 Pasca Putusan Mahkamah Konstitusi Nomor 48/PUU-XVII/2019". Jurnal Supremasi, Volume 10 No. 1, Maret 2020. Halaman 6

5Ibid halaman 6 
Negara dalam Upaya Pencegahan Penyebaran Covid 19 di Lingkungan Instansi Pemerintah.

5. Undang-Undang Nomor 6 Tahun 2018 tentang Kekarantinaan Kesehatan.

b. Bahan Hukum Sekunder adalah bahan hukum yang tujuannya untuk membantu memberikan analisis terhadap bahan hukum primer. Bahan hukum ini berasal dari buku-buku hasil tulisan ahli hukum berpengaruh, jurnal hukum, kasus hukum, pendapat sarjana maupun yurisprudensi. ${ }^{6}$ Bahan hukum sekunder yang digunakan penulis dalam penelitian ini adalah jurnal hukum yang berkaitan dengan topik permasalahan yang diteliti.

c. Bahan hukum tersier adalah bahan hukum yang digunakan untuk memperjelas bahan hukum primer maupun sekunder. Dalam penelitian ini penulis menggunakan bahanbahan dari internet dan KBBI (kamus besar bahasa Indonesia) untuk mencari penjelasan terhadap suatu istilah. ${ }^{7}$

\section{PEMBAHASAN}

\section{Tinjaun Yuridis Work From Home}

Indonesia adalah negara berpopulasi paling tinggi di Asia Tenggara dan keempat di dunia. Dengan peringkat tersebut, Indonesia memiliki sekitar 70\% (tujuh puluh persen) jumlah penduduk berusia produktif yaitu antara lima belas sampai enam puluh empat tahun. Namun lapangan pekerjaan yang tersedia tidak sebanding. Hal inilah yang membuat beberapa perusahaan menjadi asal-asalan dalam memberikan hak karyawan.

Setiap orang pada dasarnya berhak untuk mendapatkan pekerjaan dan sarana kehiduppan yang sepantasnya sebagai manusia sesuai dengan UUD NRI 1945 pasal 27 ayat 2. ${ }^{8}$ Maka dari itu, masalah dalam ketenagakerjaan harus diberikan perhatian lebih karena ketenagakerjaan berkaitan erat dengan kemanusiaan.

Semenjak pandemi Covid-19, muncul istilah Work From Home (WFH) yang mana berhubungan dengan masalah ketenagakerjaan. Rutinitas kerja yang biasanya di kantor atau perusahaan harus pindah ke rumah. Pada dasarnya, istilah WFH sudah dikenal sejak lama oleh para pekerja freelance. Sebenarnya sebelum pandemi sudah ada beberapa perusahaan yang melakukan kerja remote yang cara kerjanya hampir sama dengan WFH.

WFH berasal dari salah satu Pasal dalam Undang-undang Ketenagakerjaan. Di dalam pasal 86 ayat (1) yang menjelaskan bahwa telah mutlak dijaminkan kepada setiap pekerja/buruh atas perlindungan keselamatan dan kesehatan kerja. ${ }^{9}$

\footnotetext{
${ }^{6}$ Depri Liber Sonata."Metode Penelitian Hukum Normatif dan Empiris:Karakteristik Khas dari Metode Meneliti Hukum". Fiat Justisia Jurnal Ilmu Hukum, Volume 8 No. 1, Januari-Maret 2014. Halaman 25.

7Erlina Maria Christian Sinaga dan Sharfina Sabila "Politik Legislasi Hukum Tidak Tertulis dalam Pembangunan Hukum Nasional". Rechtsvinding, volume 8 nomor 1, April 2019. Halaman 4.

8 Undang-undang dasar 1945

${ }_{9}^{9}$ Undang-undang Nomor 13 Tahun 2013 tentang Ketenagakerjaan
} 
Perusahaan tidak dapat serta merta memotong upah pekerja karena kondisi work from home pandemi Covid-19. Karena selaras dengan yang telah diatur dalam Peraturan Pemerintah Nomor 78 Tahun 2015 tentang Pengupahan, hal tersebut bisa dianggap tidak berdasarkan hukum dan dapat menimbulkan perselisihan hubungan industrial.

Mengenai hak-hak pekerja yang dirumahkan diatur dengan jelas dalam Surat Edaran Menteri Tenaga Kerja No. 3 Tahun 2020. Hak-hak yang diberikan itu diantaranya adalah:

1. Untuk orang yang dalam pemantauan dan tidak dapat bekerja selama empat belas hari, upahnyatetap dibayar penuh.

2. Untuk suspek dan tidak dapat bekerja selama empat hari atau sampai waktu yang ditentukan oleh petugas medis, upahnya tetap dibayar penuh.

3. Untuk yang positif Covid 19 upah harus tetap dibayarkan sesuai perundang-undangan.

4. Sedangkan untuk pekerja yang work from homedengan mempertimbangkaan kelangsungan usaha perubahan besaran maupun cara pembayaran dilakukan sesuai kesepakatan antara pengusaha dengan pekerja.

Perusahaan tidak boleh memotong upah pekerja saat pandemi Covid 19, karena hal ini tidak sesuai dengan pengaturan pengupahan menurut Peraturan Pemerintah Nomor 78 tahun 2015 tentang pengupahan. Dimana dalam pasal 5 ayat 1 dinyatakan bahwa upah terdiri atas:

1) Upah tanpa tunjangan

2) Upah pokok dan tunjangan tetap

3) Upah pokok, tunjangan tetap, dan tunjangan tidak tetap.

Di dalamnya juga dinyatakan bahwa upah hanya dapat dipotong apabila telah diperjanjikan dalam perjanjian kerja, peraturan perusahaan, atau peraturan kerja bersama. Pemotongan upah tersebut digunakan untuk menjadi denda, ganti rugi, dan/atau uang muka upah.

Ditengah pandemi yang melanda, dunia ketenagakerjaanharus berhadapan dengan hari raya Idul Fitri yang mana merupakan hari raya keagamaan umat Islam. Sesuai Peraturan Menteri Ketenagakerjaan Nomor 6 Tahun 2016 Pasal 2 yang menerangkan bahwa setiap pekerja yang telah bekerja selama satu bulan terus menerus atau lebih, maka pengusaha wajib memberikan Tunjangan Hari Raya (THR). ${ }^{10}$

Namun dengan terbitnya SE Menaker No. M/6/HI 00.01/V/2020, memberikan celah bagi perusahaan untuk membayarkan THR secara bertahap bagi pengusaha yang tidak dapat membayar penuh dan menunda pembayaran THR bagi pengusaha yang tidak dapat membayar sama sekali sampai waktu yang di sepakati. Hal ini bisa saja memberikan peluang perusahaan tidak membayar tunjangan. Padahal sebagaimana diatur dalam Peraturan Menteri Tenaga Kerja No. 6 Tahun 2016 dan PP tentang Pengupahan No. 78 Tahun 2015, Tunjangan Hari Raya (THR) wajib dibayarkan. Selain itu, menurut kedua produk hukum ini, tidak diizinkan untuk menunda pembayaran THR atau mencicilnya.

10 Peraturan Menteri Ketenagakerjaan Nomor 6 Tahun 2016. 
Sebagaimana yang telah terlihat bahwa adanya ketidaksesuaian antara SE Menaker dan peraturan perundang-undangan. SE Menaker cenderung lebih memihak pengusaha. Sedangkan karyawan kurang mendapat perhatian.

Hal inilah yaang kemudian menjadi pertanyaan, karena antara keduanya saling bertentangan sehingga perlu diperjelas aturan yang mana yang harus diikuti. Kedudukan SE Menaker dibanding dengan peraturan perundang-undangan ketenagakerjaan adalah di bawahnya. Jadi SE Menaker seharusnya tidak bertentangan dengan peraturan perundangundangan. SE Menaker juga bukan peraturan perundang-undangan sehingga tidak dapat dijadikan dasar hukum. ${ }^{11}$

\section{Sanksi dan Solusi Bagi Perusahaan}

Tidak semua perusahaan dapat membuat pekerjanya bekerja di rumah. Beberapa perusahaan tidak dapat membuat pekerjanya bekerja dari rumah. Perusahaan tersebut diantaranya yang memiliki alat-alat berat yang tidak dapat dibawa kerumah. Perusahaan yang tidak dapat mempekerjakan karyawannya dari rumah, harus menyediakan Alat Pelindung Diri (APD).

Mengenai APD yang disediakan perusahaan harus sesuai dengan potensi bahaya dan resiko yang ditimbulkan. Penyediaan APD sebagaimana yang telah diatur dalam UndangUndang No. 1 Tahun 1970 tentang Keselamatan dan Kesehatan Kerja. Di dalamnya diatur bahwa pekerja boleh menolak untuk bekerja jika pengusaha atau perusahaan tidak menyediakan APD.

Tidak ada sanksi dalam menjalankan WFH. Karena sifat dari Surat Edaran tersebut adalah sebagai himbauan. Sehingga masih banyak perusahaan yang tidak mengizinkan pekerjanya agar bekerja dari rumah.

Di tengah pandemi yang melanda, perusahaan telah kehilangan omset yang banyak sehingga perusahaan tidak daapat membayar karyawannya sesuia dengan upah minimum yang di tentukan. Melakukan penangguhan upah adalah solusinya. Penangguhan pelaksanaan upah minimum adalah untuk membebaskan perusahaan dalam kurun waktu tertentu untuk memberikan upah dalam ketentuan upah minimum. Apabila telah habis masa waktunya, maka perusahaan wajib kembali membayar sesuai ketentuan upah minimum.

Pada dasarnya, membayar pekerja/buruh dibawah standar upah minimum dilarang bagi setiap pengusaha. Hal ini telah diatur secara jelas dalam pasal 90 UU Ketenagakerjaan yang menerangkan bahwa:

1. Seperti yang telah diatur dalam pasal 89, yaitu larangan bagi pengusaha untuk membayar upah kurang dari upah minimum

2. Dapat dilakukan penangguhan pengupahan bagi pengusaha yang tidak dapat membayar upah sesuai dengan ketentuan upah minimum

3. Adapun prosedur penangguhan diatur dalam Keputusan Menteri

\footnotetext{
${ }^{11}$ Guna, Dedi. 2020.Surat Edaran Menaker di masa Covid-19 bagaimana kedudukannya sebagai produk hukum. https:kawanhukum.id diakses 27 Juli 2020
} 
Tata cara penangguhan membayar upah minimum telah ditetapkan dalam Keputusan Menteri Tenaga Kerja dan Transmigrasi Nomor KEP-231/MEN/2003 Tahun 2003 mengenai Tata Cara Penangguhan Pelaksanaan Upah Minimum. Pengusaha yang mengalami kesulitan membayar upah untuk para pekerjanya dapat mengajukan penangguhan kepada gubernur. Permohonan penangguhan tersebut diajukan melalui instansi yang berwenang di bidang ketenagakerjaan.

Permohonan tersebut diajukan dari hasil perundingan antara pengusaha dengan pekerja atau serikat pekerja yang tercatat yang telah disepakati. Sehingga hal ini jelas bahwa dalam mengajukan penangguhan upah minimum harus merupakan kesepakatan bersama antara keduanya.

Jika telah tercapai kesepakatan tentang upah minimum, maka langkah selanjutnya adalah mengajukan permohonan kepada gubernur. Untuk dapat mengajukan penangguhan upah minimum, maka permohonan harus di sertai dengan:

1. Hasil kesepakatan antara pengusaha dengan serikat pekerja yang bersangkutan yang dituangkan dalam naskah asli

2. Laporan keuangan yang menerangkan hasil perhitungan laba/rugi perusahaan disertai dengan penjelasan dan neracanya dalam kurun waktu 2 (dua) tahun terakhir.

3. Memberikan salinan akta pendirian perusahaan.

4. Memberikan laporan daftar gaji buruh berdasarkan tingkat jabatannya

5. Memberikan jumlah seluruh pekerja/buruh seluruhnya dan yang dimohonkan penangguhan pelaksanaan upah minimum.

6. Perkembangan dan rencana produksi maupun pemasaran selama 2 (dua) tahun terakhir dan 2 (dua) tahun yang akan datang.

Jika perusahaan yang mengajukan penangguhan pelaksanaan upah minimum adalah perusahaan yang berbentuk badan hukum atau gubernur perlu untuk membuktikan bahwa perusahaan tersebut benar-benar tidak mampu dalam keuangannya, maka laporan keuangaan harus diaudit terlebih dahulu.

Gubernur akan memberikan persetujuan atau penolakan terhadap permohonan yang diajukan setelah Dewan Pengupahan Provinsi memberikan saran dan pertimbangan. Dalam hal ini, jika gubernur menyetujui maka akan diberikan waktu penangguhan selama paling lama 12 (dua belas) bulan.

Bentuk penangguhan upah minimum dapat berupa:

a) Upah dibayar berdasarkan upah minimum yang lama;

b) Upah dibayarkan lebih tinggi dari standar upah minimum lama dan lebih rendah dari yang baru;

c) Upah minimum dinaikkan secara bertahap. ${ }^{12}$

12 Pramesti, Tri Jata Ayu.2019. Penangguhan pelaksanaan upah minimum bagi perusahaan tidak mampu. https:hukumonline.com. diakses pada 27 Juli 2020 


\section{PENUTUP}

Undang-Undang Ketenagakerjaan telah membahas banyak hal baik tentang hak-hak karyawan hingga sistem pengupahan. Di tengah pandemi ini telah diterbitkan Surat Edaran Menteri baik mengenai WFH dan sistem pengupahan termasuk di dalamnya pembayaran THR yang dapat diangsur yang mana bertentangan dengan Peraturan Menteri Tenaga Kerja No. 6 Tahun 2016 dan PP tentang Pengupahan No. 78 Tahun 2015 yang memiliki kedudukan di atasnya.

Tidak ada sanksi tentang pemberlakuan WFH. Perusahaan yang tidak dapat merumahkan pekerjanya maka harus menyediakan APD. Tentang upah yang harus dibayarkan, jika pengusaha tidak dapat memberi upah sesuai dengan aturan UMP, maka pengusaha dapat mengajukan penangguhan kepada Gubernur.

\section{DAFTAR PUSTAKA}

\section{Perundang-Undangan}

Undang-Undang Dasar Negara Republik Indonesia 1945

Undang-Undang Republik Indonesia Nomor 13 Tahun 2003 tentang Ketenagakerjaan

Peraturan Menteri Ketenagakerjaan Nomor 6 Tahun 2016

\section{Jurnal}

Perdana, M. Taufan, Moh. Alfaris, Anik Iftitah, "Kewenangan BAWASLU Dalam Pilkada2020 Pasca Putusan Mahkamah Konstitusi Nomor 48/PUU-XVII/2019”. Jurnal Supremasi, Volume 10 No. 1, Maret 2020.

Sonata, Depri Liber. "Metode Penelitian Hukum Normatif dan Empiris:Karakteristik Khas dari Metode Meneliti Hukum". Fiat Justisia Jurnal Ilmu Hukum, Volume 8 No. 1, Januari-Maret 2014.

Sinaga, Erlina Maria Christian dan Sharfina Sabila. "Politik Legislasi Hukum Tidak Tertulis dalam Pembangunan Hukum Nasional". Rechtsvinding, Volume 8 No. 1, April 2019.

\section{Artikel Online}

Ramadayanti, Ega 2020. Covid-19 dalam perspektif one health approach dan law enforcement, fh.unpad.ac.id diakses tanggal 13 April 2020

Admin. Bermasalah Terkait Pekerjaan Karena Pandemi COVID-19?: 16 Kantor LBH-YLBHI Membuka Posko Pengaduan Bantuan Hukum Online. lbhyogyakarta.org. diakses 13 April 2020

Pramesti, Tri Jata Ayu.2019. Penangguhan pelaksanaan upah minimum bagi perusahaan tidak mampu. https:hukumonline.com. diakses pada 27 Juli 2020

Guna, Dedi. 2020. Surat Edaran Menaker di masa Covid-19 bagaimana kedudukannya sebagai produk hukum. https:kawanhukum.id diakses 27 Juli 2020 